\title{
ОСОБЕННОСТИ РЕАЛИЗАЦИИ КОНЦЕПЦИИ СОЦИАЛЬНО-ЭТИЧНОГО МАРКЕТИНГА В СОВРЕМЕННЫХ ОБРАЗОВАТЕЛЬНЫХ ОРГАНИЗАЦИЯХ
}

\author{
(c) 2020 Максаев Артур Анатольевич \\ кандидат педагогических наук, доцент, кафедра менеджмента и торгового дела \\ Краснодарский кооперативный институт (филиал) \\ АНОО ВО Центросоюза РФ «Российский университет кооперации», Россия, Краснодар \\ E-mailmaksaev@mail.ru
}

Актуальность темы научной статьи связана с необходимостью обеспечения социальной ответственности и этичности реализации маркетинговых воздействий в современных образовательных организациях. Выбранное научное поле относится к числу наименее развитых научных проблем организации маркетинга в отраслях и видах деятельности, поскольку в настоящее время в современных вузах преобладает производственно-сбытовой подход к организации взаимодействия с субъектами образовательной системы маркетинга. Объект исследования - управленческие отношения, сопровождающие выработку и реализацию маркетинговой стратегии современного вуза на основе концепции социально-этичного маркетинга, предмет исследования - корпоративная социальная ответственность вузов и ее возможности в качестве долгосрочного маркетингового приоритета. Теоретико-методологическое значение темы научной статьи состоит в обосновании теоретического базиса и подходов к решению проблем социальной ответственности в маркетинговой стратегии современных вузов. Практическое значение темы связано с возможностью разработки и реализации конструкции социально ответственного маркетинга образовательной организации.

Ключевые слова: Корпоративная социальная ответственность. Социально ответственный маркетинг. Теоретическая конструкция социально ответственного маркетинга университета.

Университеты как образовательные учреждения играют жизненно важную роль в развитии и совершенствовании общества, способствуя его благосостоянию его граждан. Заинтересованными сторонами социальной ответственности университетов являются студенты, учреждения, правительства, сотрудники, компании, НКО, фонды, местные сообщества и другие субъекты. Мы рассматриваем университет как корпоративную организацию, которая разрабатывает стратегические планы и социально ответственную практику.

Чем ближе мы приблизимся к более точному пониманию сути социально ответственного маркетинга бизнеса (COM), тем яснее станет подход к трактовке социально ответственного маркетинга университета (СОМУ). Концептуальный подход к пониманию логики развития СОМУ позлит менеджерам маркетинга университетов разработать собственную стратегию реализации его социальной миссии средствами маркетинга. Многочисленные теоретические исследования и усилия по классификации, относящиеся к КСО, встречаются в литературе по менеджменту, ограничивая маркетинг лишь несколькими, но ценными категориями теоретических перспектив. Кроме того, когда специалисты по маркетингу впервые начали обсуждать аспекты, связанные с КСО в рамках дисциплины, они первоначально сосредоточились на расширении концепций маркетинга, а затем проанализировали социальные функции бизнеса, чтобы сосредоточиться на стратегических способах использования этой конструкции.

Разработанность темы COУ в литературе. В первом десятилетие 2000-х гг. российские ученые приступили к научному обоснованию взаимодействия трех субъекты рынка высшего образования: государство - университет - общество. Проблемы корпоративной социальной ответственности (КСО) давно стали предметом западных исследований. Для поиска теоретической конструкции этого взаимодействия потребовалось привлечение знаний, относящихся к КСО бизнеса развитых государств [1-7].

Развитая экономика характеризуется высокой конкуренцией за внимание потребителей, представляющих различные общественные группы. Государство в таких экономиках, выступает как равноправный субъект рынка, как 
суперсубъект, обладающий огромными преимуществами перед другими представителями бизнеса, размещения государственных заказов, часто корпоративного формата, регулирование налогообложения, выдачи кредитов, грантов.

Высокий уровень конкуренции вызвал острую борьбу среди крупных компаний за внимание потребителей к имиджу своих брендов и компаний. Как только меняется макроэкономическая среда, меняется и поведение потребителей, а значит должен меняться маркетинг. Эта ситуация потребовала от бизнеса подходить к оценке спроса на свои бренды не только с позиций изучения рынка покупательских сегментов, но с позиции характеристик покупателей в качестве личностей представителей общества. Первым, кто из исследователей маркетинга обратил на это внимание, был Ф.Котлер [1]. Книга авторов «Маркетинг 3.0» - это этап, когда компании переходят от ориентации на потребителя к ориентации на человека, когда погоня за рентабельностью сочетается с корпоративной ответственностью. Новая идея социально ответственного маркетинга требует от компаний и организаций преподносить свою миссию, видение и цели для каждой из заинтересованных сторон: служащие, распространители, продавцы, поставщики, акционеры. Компания получает прибыль, создавая потребительную стоимость для своих клиентов и партнеров. Преследуя свои вполне корыстные цели - получение прибыли (материальной и нематериальной), компании видят перед собой не только своих потребителей, но полноценных людей со всеми их потребностями и желаниями.

Теоретические основы социальной ответственности университета - СОУ. Социальная ответственность в самом простом понимании означает, что организации, помимо максимизации своей стоимости, должны действовать таким образом, чтобы его результаты шли на пользу обществу.

Концепция CO учитывает наиболее важные проблемы различных общественных аудиторий в отношении между бизнесом и обществом [4].

КСО является долгосрочным обязательством, взятым на себя компанией, и оно оказывает растущее влияние на разработку своей корпоративной стратегии. С учетом многочисленных определений СО можно предложить следующее определение. СО - новый способ ведения бизнеса, при котором компания устойчивым образом управляет своей экономической, социаль- ной и экологической деятельностью, учитывая интересы различных общественных аудиторий, к которым она относятся. В последние годы корпоративная социальная ответственность рассматривается как устойчивость бизнеса и потому, естественное его взаимодействие с обществом. Аналогичным образом, некоторые этические аспекты и аспекты СО учитываются в маркетинговых стратегиях компаний, основанных на этой перспективе.

Социальный маркетинг (благотворительность или патронаж) - это понимание компанией (университетом) проблем, которые затрагивают общество с определенной точки зрения. Эта область касается конкретных приложений маркетинга для решения социальных задач, с которыми сталкиваются отдельные представители социума. Социальный маркетинг использует свои методы с целью изменения поведения части общества для пользы общества в целом, включая пользу отдельных личностей, на которых он нацелен.

Социально ответственный маркетинг своей маркетинговой деятельностью оказывает воздействие на общественные интересы и ценности. Кардинальные изменения в корпоративной культуре университета, неизбежно ведут к трансформации его классической миссии. Это связано с наращиванием объема коммерческой активности [5].

Университет постепенно утрачивает свой научно-образовательный статус и превращается в экономическую корпорацию, фабрику по производству науки и профессиональных специалистов, где естественным образом сочетаются корпоративные и общественные интересы. Университетам, также как и аналогичным учреждениям образования, воспитания и здравоохранения имманентно присуща корпоративная социальная ответственность. Они и есть воплощение социальной ответственности, по смыслу и замыслу своего существования. Вузы считаются актуальными с точки зрения их способности влиять на самые разные группы интересов студентов, сообществ и общество в целом. Деятельность и учреждение государством этих структур в интересах общества создана и призвана ему во благо.

Заинтересованные стороны СОМУ. Участники, заинтересованные стороны процесса СОМУ (стейкхолдеры). Стейкхолдеры - это любые индивидуумы, группы или организации, 
оказывающие существенное влияние на принимаемые организацией решения и/или оказывающиеся под воздействием этих решений [6].

Внутренние заинтересованные стороны СО университета: студенты, абитуриенты (семьи) преподаватели, сотрудники, ученые, административный состав, специалисты маркетинга, рекламы, PR и GR университета (модераторы). Внешние заинтересованные стороны: работодатели, руководящие и контрольные органы власти в сфере образования, региональные субъекты власти и экономики, выпускники, потребители образовательной продукции, инвесторы, общественные, профессиональные гильдии, ассоциации, объединения, союзы, НКО, фонды, окружающая среда, общество в целом.

Уровень профессионализма и компетентность специалистов маркетинговых служб (модераторов) - залог успеха или не успеха реализации стратегии СОУ. Хотя некоторые авторы утверждают, что все заинтересованные стороны равны и ни один не имеет приоритета над другим, все же каждый сегмент в структуре заинтересованных лиц СОУ требует особой стратегии и установления рабочих отношений. Ценность СОУ обусловлена преимуществами, которую оно приносит сообществу заинтересованной стороны. В этом плане студенты и их участие в университетских задачах заслуживают особого внимания, прежде всего потому, что они представляют самый значительный сегмент потребителя при получении необходимой подготовки для их профессионального обучения. Другие заинтересованные стороны, такие как академический и административный персонал, также получают выгоду от улучшения своей учебной и управленческой работы. С позиции общественной пользы важны достижения выпускников, готовых к решению этических задач и поддержке ценностных позиций, необходимых на рынке труда. Когда университет стремится быть конкурентоспособным, ему необходимо осознать, соответствует ли его деятельность потребностям заинтересованных сторон и, возможно, необходимо построить более прочные стратегические отношения с ними, чтобы эффективно реагировать на изменения в секторе высшего образования.

Принципы формирования теоретической конструкции СОМУ.

1. СОУ рассматривается в качестве стратегии, если его миссия и цели скоординированы.
2. Активность СО университета определяется его экономической и политической устойчивостью, для которой характеры черты стабильности и рентабельности.

3. СО - это всегда результат отношений. Связь между маркетинговыми инициативами и результатами СО эффективна, если в этот процесс включены заинтересованные стороны.

4. СОМУ должен применяться в целях, выходящих за рамки продвижения только образовательной продукции (образовательных услуг, результатов НИР).

5. Маркетинговые воздействия на общество командой университета создает дифференцирующую для него позицию на рынке образования для построения репутации, корпоративного имиджа.

6. Маркетинговые действия университета СО не должны быть навязаны внешними нормами, их основу составляют ценности университета, их формулировка должна соответствовать ожиданиям заинтересованных сторон и предвосхищать их ожидания (проактивность действий).

7. Эффективность маркетинговых действий в разработке программ и проектов СО зависит от профессиональной компетентности специалистов маркетинговых служб университетов (посредников, модераторов СО).

8. СОУ должна носить публичный и открытый характер. Здесь огромную роль играют сайт, социальные медиа [6].

Будущее социально ответственного маркетинга университета. В настоящее время мы наблюдаем зарождение СOУ. Что же на самом деле происходит в каждом конкретном университет, которые использует маркетинговые стратегии социальной ответственности, можно узнать только из отчетов и специальных исследований, которые сложно найти в открытых источниках. Крупнейшие корпоративные благотворительные программы обусловлены как стратегическим, так и коммерческим интересом, и их основной мотивацией является сочетание желания завоевать большую долю рынка, улучшения имиджа общества и поощрения мотивации персонала и конкуренции на рынке труда.

Будущее СОМУ зависит от масштаба процесса формирования более крупных национальных и глобальных университетов, чем мы наблюдаем сегодня. Будущее СОМУ также зависит от скорости и глубины осознания заинтересованных 
сторон, что этические и экономические вопросы сосуществуют рядом друг с другом. Концепция социально ответственного маркетинга университета провозглашает своей задачей удовлетворение не только потребностей университетского сообщества, но и укрепление благополучия общества в целом.

Мы уверены, что маркетинговые практики воздействия университета на общество будут постоянно развиваться. Это указывает на не- обходимость нового подхода к маркетинговым функциям в университетах. Управление социальной ответственностью университета должно основываться на выявлении всех заинтересованных сторон, налаживании диалога и длительные отношений с ними, создание общей ценности через обмен, который может принести пользу всем вовлеченным сторонам в процесс созидания общественного устройства и благополучия.

\section{Библиографический список}

1. Котлер Ф. Маркетинг 3.0: от продуктов к потребителям и далее - к человеческой душе.- М.: Эксмо. 2010.240 c.

2. Резник С.Д. Организационная культура российского студенчества в условиях изменений социальноэкономической среды. М, ИНФРА-М. 2020.-176 с

3. Смирнова В.Г. Организационная культура. М.: ЮРАЙТ. 2019.- 306 с.

4. Шевченко Д. А. Маркетинг образования в России. М.: ЮНИТИ-ДАНА, 2017.- 447 с.,

5. Шевченко Д. А. Рынок диджитал коммуникаций в России: ситуация и основные тренды// Системные технологии. 2018. № 1 (26). С. 84-89.

6. Шевченко Д. А. Сайт вуза: методика оценки // Социологические исследования. 2014. № 5 (361). С. $143-152$.

7. Шейн Э. Х. Организационная культура и лидерство / Пер. с англ. под ред. В. А. Спивака. СПб, Питер, 2002.$336 \mathrm{c}$. 